\title{
LEGAL ACCOUNTABILITY OF PUBLIC ACCOUNTANTS IN THE FINANCIAL STATEMENT BASED ON INDONESIA'S LEGAL SYSTEM
}

\author{
Raja Sirait1 $^{1}$; Made Warka ${ }^{2}$; Krisnadi Nasution² ${ }^{2}$ Otto Yudianto ${ }^{2}$ \\ ${ }^{1}$ Raja Sirait and Partners Lawfirm, Jakarta, Indonesia \\ ${ }^{2}$ Faculty of Law, Universitas 17 Agustus 1945, Surabaya, Indonesia \\ Email: rajasirait62@yahoo.com; made@untag-sby.ac.id; krisnadin@yahoo.com; \\ otto@untag-sby.ac.id
}

\begin{abstract}
The purpose of this study is to examine further regarding of the legal accountability of the public accountants on financial statements in the Indonesian legal system. This research is important to conduct due to the public accounting profession that has a significant role to express opinions about fairness in all material matters, financial position, results of operations, changes in equity, and cash flows in accordance with general accounting principles accepted in Indonesia. In other words, the responsibility of public accountants is to express opinions on financial statements. Public accountants are responsible for planning and carrying out audits in order to obtain adequate assurance about whether the financial statements are free from material misstatement, whether caused by errors or fraud. Financial statements are the responsibility of management, and the public accounting profession cannot just be punished. This research is a normative legal research. The data used is secondary data consisting of primary legal materials, secondary legal materials and tertiary legal materials. The data collection techniques use literature study, while data validation techniques use source criticism. The data is analyzed by using legal interpretation methods to obtain answers to the questions examined. The results show that a public accountant can have criminal and civil liability in carrying out the duties when publishing a company's financial statements.
\end{abstract}

Keywords: criminal responsibility, civil liability, public accountants, financial statements.

\section{A. INTRODUCTION}

The demand for public accountant service users is currently increasing, especially the demand for financial information quality that used as one of the considerations in economic decisions making which play a role in the era of free trade and satisfy the demand of service users. In order to support the accomplishement of the demands of service users and protect the interests of the community and at the current time protect their profession, public accountants are required to constantly improve their competence and professionalism. Public accountant is a profession supporting

Yustisia Vol. 7 Number 3 (Sept.-Dec. 2018)

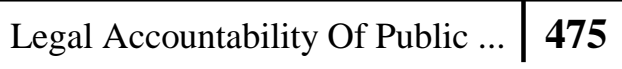

C2018; This is an Open Acces Research distributed under the term of the Creative Commons Attribution Licencee (https://Creativecommons.org/licences/by/4.0), which permits unrestricted use, distribution, and reproduction in any medium, provided the original works is properly cited. 
business activities, especially in the era of trade in goods and services. Therefore, the demand for public accountant service users is increasing, especially the demand for financial information quality that used as one of the considerations in economic decisions making. Public accountant is professions that are built in and grow derive the public demands for an independent communication mechanism between economic entities and stakeholders, especially with regard to the accountability of the entity concerned (Mardiasmo, 2006).

Observing the rapid development of the public accounting profession, Indonesia Government conducts arrangement related to the practice of public accountants by issuing the Minister of Finance Regulation Number 17 / PMK.01 / 2008 dated 5 February 2008 concerning Public Accountant Services. This rule aims to create effective and sustainable arrangement, guidance and supervision of this profession, Public Accounting Firm and protect the public interest. In addition, the Government has also enacted Law Number 5 of 2011 concerning Public Accountant (hereinafter referred as Public Accountant Act).

However, until now, the law enforcement against fraudulent practices carried out by public accountant in financial statements was unable to enforce the justice. The maximum sanction given to this profession is administrative sanctions in the form of license revocation. For this reason, several public accountants supported by the Indonesian Institute of Certified Public Accountants submitted an application to review the Public Accountant Act to the Constitutional Court registered with Case Test Number 84 / PUUIX / 2011. The Public Accountant Act test aims to examine further the basic idea of construction of criminalization and penalization of the public accounting profession regulated in Articles 55 and 56 of the Act. The rejection of such Act has actually begun since the it was drafting until it is approved as a regulation.

This study aims to examine further regarding how the criminal accountability of public accountants in publishing corporate financial statements in the perspective of Indonesian Law. In addition, this study also examines the process of criminalization policies carried out by legislators, especially regarding the arguments that developed during the course of the Case Test Number 84 / PUU-IX / 2011 concerning Testing of articles 55 and 56 of Law Number 5 of 2011 concerning Public Accountant towards the 1945 Constitution of the Republic Indonesia.

\section{B. PROBLEM STATEMENT}

This study sharply examines on how the criminal accountability of public accountants in publishing corporate financial statements within the perspective of Indonesian Law.

476 Yustisia Vol. 7 Number 3 (Sept.-Dec. 2018) $\quad$ Legal Accountability Of Public ... 


\section{RESEARCH METHODS}

This study focuses on the positive law (legislation), which considered normative. Positive law has both normative and imperative characters. In which, positive law is the command or will of the authorities to be carried out, and demands that this command be adhered appropriately (Moch. Koesnoe, 1981). In accordance with the character of positive law, the emphasis of normative legal research lies in the study of the problem of legislation in a coherent legal order (Soetandyo Wignyosubroto, 1995). The data used in this study were secondary data consisting of primary legal materials, secondary legal materials, and tertiary legal materials. Data collection techniques use literature, while data validation techniques use source criticism. Further, the data was analyzed by legal interpretation methods to gain answers of the question.

\section{DISCUSSION AND RESEARCH RESULTS}

\section{Fair Finacial Statement of Company}

The principle of accounting (accounting principle) is a proposition or doctrine to oversee a system or certain activities that have been approved by the truth. The accounting principle is not an essential truth in the field of accounting, because in essence, accounting always develops and always changes in accordance with developments and changes in values that occur in society (Theodorus M. Tuanakotta, 2010).

Meanwhile, auditing for companies is quite important because it gives a big influence on the activities of the company concerned. At the beginning of its development, auditing was only intended to find and find fraud and errors. But along with its development, auditing then developed into the examination of financial statements to provide opinions on the truth of the presentation of the company's financial statements and also become one of the factors in decision making (Alvin A. Arens, Randal J. Elder, Mark S. Beasley, 2003).

As the company develops, the audit function is increasingly important and needs arise from the government, shareholders, financial analysts, bankers, investors, and the public to assess management quality from the results of operations and the achievements of managers. To overcome these needs, a management audit system is created as a trusted tool in helping implement their responsibilities by providing analysis, assessment, recommendations on activities that have been carried out (Alvin A. Arens, Randal J. Elder, Mark S. Beasley, 2003). 


\section{Disclosure Principle in Submitting Financial Statements.}

Article 1 number 25 of the Capital Market ACt states that:

"... the disclosure principle is a general guideline that requires issuer, public company, and other persons subject to under this law to disclose to the public with a certain time, material information with respect to their business or securities, when such information may influence decision of investors in such securities and/or the price of the securities"

This disclosure principle is the main problem in the study of capital markets and at the same time is the spirit of the capital market itself. Disclosure of material facts as the point of the capital market is based on the existence of the disclosure principle that allows the as consideration for investors to make decisions rationally in the context of buy or sell shares (http: //perturanlk-bapepam).

The practices in the capital market nowadays show that disclosure principle is often violated. One form of violation is a misleading statement or misleading information results in the creation of a description of condition which different from the actual situation later misleads the users of financial statements, especially investors or shareholders of public companies. In addition, misrepresentations often occur in financial statements regarding a misleading financial statement further becomes a misleading financial statement, which is manipulative. In the Decision of the Capital Market Supervisory Agency (Bapepam) Number Kep-86 / PM / 1996 concerning disclosure of information must be announced to the public (Rule Number XK1) inter alia, determines that if an event or material fact occurs, it must be reported to Bapepam and announce it to the public no later than two working days after the event. Accurate, timely and transparent disclosure of all matters that are important for company performance, ownership, and stakeholders aim to give consideration in making decisions by the directors and commissioner councils in order to attain disclosure to the stakeholders through four approaches, such as relevant, reliable, comparable and understandability (Bismar Nasution, 2003).

Any information disclosed must be audited in advance in order to gain high quality standards. The audit process must be carried out by an independent auditor to provide independent information to external parties. The path of information dissemination must reflect fairness, timeliness and cost efficiency so that information is relevant (Bismar Nasution, 2003).

\section{Legal Status of Independent Public Accountants}

The provisions of Article 68 regarding to the Limited Liability of Company Act regulates the financial statement of company that must be audited by public 
accountants in which not being implemented will result in the financial and annual reports not approved by the General Meeting of Shareholders.

According to Mulyadi, audit is a systematic process for obtaining and evaluating evidence objectively concerning statements in regards of economic activities and events, with the aim of determining the level of conformity between the statements and the criteria that have been set, and delivering the results to users who have the interest (Mulyadi, 1990). Therefore, the auditor has strong position in establishing fair company and obtaining high trust from stakeholders.

\section{Decision Number 84 / PUU-IX / 2011 of Constitutional Court regarding to Cancelation of Article 55 and 56 of Law Number 5 of 2011 concerning Public Accountants.}

According to public accountants, Article 55 and Article 56 of the Public Accountants Act contradicts with several provision in the 1945 Constitution of The Republic Indonesia which resulted in the absence of legal uncertainty. This is due to the reason that Article 55 (a) of the a quo law contains the word "manipulation" which means vague because the act of manipulation is not recognized under the formulation of the Criminal Code as a basic provision in criminal law. In the practice of the public accounting profession, manipulation in the audit is actually interpreted as a positive thing. In the audit, the term "data manipulating" or "data manipulation" means an investigator or auditor analyzes data stored in various data storage media to find something being sought. Thus, the term "manipulation" has obviously caused ambiguity and multiple interpretations when faced with an act suspected of manipulation.

The vagueness of the "manipulation" word resulted in legal uncertainty that contradicts the guarantee the right to legal certainty as referred in Article 28 (d) paragraph (1) of the 1945 Constitution of The Republic Indonesia. If the definition of data manipulation in the a quo Public Accountant Act is applied to work the accounting profession, an auditor may be accused of manipulating data because the use of computer program to process data. This is what actually makes a public accountant in a situation that is threatened when doing his work even though it has been done correctly. Public accountants can be accused of manipulating data even though it is carried out following a computer program which is a tool of work. Thus, the term "manipulation" which has consequences on punishment has created a feeling of insecurity or extreme fear so that public accountants feel free to carry out their profession to do or not acting as guaranteed in Article $28 \mathrm{G}$ paragraph (1) of the 1945 Constitution of The Republic Indonesia.

Furthermore, public accountants deliberately manipulate, falsify, and / or eliminate data or records on paper work or do not make working papers relating 
to services provided as referred in Article 3 paragraph (1) of Public Accountant Act that further cannot be used as examinations by the competent authorities is punished by imprisonment of a maximum 5 (five) years and a penalty of a maximum Rp. 300,000,000.00 (three hundred millions rupiah). This provision contraditcs with Article 28 D paragraph (1) of the 1945 Constitution of The Republic Indonesia for several reasons:

a. The phrase "manipulation" has vague definition under Criminal Law, therefore it rises ambiguity or multiple interpretations when faced with an alleged act argued by a Public Accountant related to Article 55 (a) of the Public Accountants Act.

b. The phrase "eliminating data or notes on paperwork or not making paperwork" raises multiple interpretations because the form and process of compiling working papers varies greatly because the standards for their formation (Public Accountant Professional Standards) is only basic point and full of professional judgment. In addition, paper work for audit services, review ones, and other services as a form of public accounting services are various based on the quality of preparation. Paper work for audit services must be prepared to obtain a reasonable assurance, paper work for review services to obtain limited assurance (adequate confidence), paper work for review service to obtain another services in order to gain very limited assurance (low confidence of limited assurance) and paperwork for other services arranged to obtain very limited assurance (low confidence of limited assurance). Thus making the compilation of paper as a convicted act is very difficult to measure the elements of his actions.

c. The phrase "it cannot be used properly in the framework of examination" means vague. The meaning of "cannot be used properly" does not have clear and definite standards or subjective (depend on the examiner).

d. The phrase "inspection by the competent authorities" is vague due to the explanation which stated that competent authority may includes the Minister, the police, the prosecutor's office, and the court. Take into account that the police, prosecutors and courts do not have the qualifications and interests to check the quality of the paper work.

Meanwhile, Article 55 (b) of the Public Accountants Act contradicts with Article 28G paragraph (1) of the 1945 Constitution of the Republic Indonesia, because the provision of a quo has created extreme insecurity or fear that Public Accountants feel that they are not free to carry out the profession to do or not do. This is based on reasons as explained below:

480 Yustisia Vol. 7 Number 3 (Sept.-Dec. 2018) $\quad$ Legal Accountability Of Public ... 
a. Article 55 letter (b) of the a quo law states that deliberately manipulating, falsifying, and/or removing data or records on paper work or not making working paper is excessive, considering the nature of the working paper itself which is not a final document. In other words, the characteristics of Public Accountant's work product is an opinion or public accountant opinion on a financial statement or financial information, an opinion is a reasonable assurance and is not an absolute statement of financial statements or financial information.

b. The formation of the law governing the profession of Public Accountant should be based on customary law that applies in the practice of the profession of the Public Accountant. Therefore, the phrase in Article 55 letter (b) which states "eliminating data or records on paperwork or not making working paper", is an administrative ethical act that violates the Public Accountant Professional Standards. Thus, settlement or ethical and administrative sanctions are more appropriate so that they are not necessarily excessive and demonstrative. In the opinion of the Public Accountants, the legislators do not consider the behavior contained in Article 55 letter (b) of the a quo law which become the domain of the private ethics not the public ethics. Furthermore, the phrase "cannot be used properly" in Article 55 (b) of the a quo law has vague definition (obscur libel) due to the size which cannot be used as it should be makes very multi-interpretive definition. The legislators should formulate more clear and itemized (the principle of lex certa or bestimmtheitsgebot) regarding actions ultimately subject to criminal sanctions. The legislator must also clearly define without being vague (nullum crimen sine lege stricta), therefore there is no ambiguous and vague formulation regarding acts that are prohibited and sanctioned. Vague or complex formulations will only create legal uncertainty.

c. Criminal threats should not be used if the by-products generated are more detrimental than criminalized acts. In other words, criminal threats should not be used to achieve as a pupose which basically could be achieved in other ways as effective as suffering and fewer losses.

The profession of public accountants prioritizes the trust of service users, the use of penal facilities as contained in Article 55 of the a quo law will threaten the continuity of insurance services carried out by public accountants. If the profession of public accounting is always faced with criminal law, then this profession will become very vulnerable and people will be reluctant to become Public Accountants. Such conditions will reduce the number of public accountants in Indonesia that are very far behind other countries in ASEAN. Especially since 
2015 Indonesia has faced liberalization of service including public accounting services for the ASEAN region.

Article 55 (b) of the Public Accountants Act is contrary to Article 28I paragraph (2) of the 1945 Constitution of the Republic Indonesia because that article a quo has created profession discrimination in public accountants with other professions relating to financial audits and data presentation. In regard of the journalist profession, based on Law Number 40 of 1999 concerning to the Press, criminal provisions are not provided or even giving criminal threats to people who obstruct journalists' work. Article 56 of the Public Accountants Act has created extreme insecurity or fear that put Public Accountant and the partners feel they are not free to carry out their work in to do or not to do.

The politics of criminal law used in the provisions of Article 56 of the a quo law is beyond the use of criminal law which emotionally means as mere retaliation. Particularly for the acts as stipulated in Article 55 (b) of the a quo law which is also imposed on the associated party is very improper because it punishes an act which is not clear who is the victim or what is the loss. In addition, the formulation of primary legal norms and secondary legal norms in Article 56 of the a quo law (secondary norm) immediately refers to Article 55 of the a quo law (primary norm) resulting in obscurity of definition (obscur libel).

Based on the description above, arguments and ratios of legislation can be examined and the construction intended to be built in formulating the lawsuit to the Constitutional Court under the criminal provisions of Articles 55 and 56 in Law Number 5 of 2011 concerning Public Accountants are as above :

a. Construction in the formulation norm is based on the argumentation of the demand for legal protection to the public, especially the community users of public accounting services. This aspect of protection to the public becomes an argument in the debate that took place in the session of the Constitutional Court.

b. The second construction is based on aspects of legal certainty. This aspect of legal certainty is associated with a clear and more specific formulation of acts that are prohibited and given criminal sanctions in which they are considered more specialist (lex specialists) compared to the formulations in the Criminal Code which only provide general provision. This argument shows that there is an inequality in the definition of criminalization which actually means the formulation of norms in the context of criminal provisions.

c. The third construction based on the realization of the transparency aspects of financial statement by public accountants. This aspect is more relied on the cases report on financial manipulation by several big companies in the

482 Yustisia Vol. 7 Number 3 (Sept.-Dec. 2018) $\quad$ Legal Accountability Of Public ... 
world such as Enron, which allegedly involved public accountants and public accounting firms.

d. The fourth construction based on the professionalism of public accountants will be further increased by diverting some rules of ethics such as "paperwork" into the public sector, as for criminal sanctions can be imposed. Criminal sanctions are aimed at public accountants or public accounting offices that violate the Public Accountant Professional Standard, whereas SPAP violations which are the ethical code of public accountants as part of the private domain of can be used to resolve internal organizational mechanisms of the public accounting profession (Institute of Accountants Indonesian Public / IAPI).

e. The fifth construction is based on the deterrent effect. The provision of criminal sanctions is expected to provide a deterrent effect on public accountants who are conducted improper and correct act.

f. The sixth construction relies on panic (moral panic) related to the alleged global situation involving rogue public accountants in several big cases such as Enron involving the Artur Andersen, Satyam and World com.

The construction of this concept can be equated with the harm principle, this concept of subsociality is taken into account in exploring and examining an act or activity that should be constructed as a criminal act or not. Means, in committing criminalization, in addition to paying attention to the alignment of principles in criminal law (schuld/error, unlawfulness/mistreatment of actions) also must examine the existence of real disturbances in other people/society. In this connection, Lon L Fuller described as "a system for governing human act by formally enacted rules". This legal production process is inseparable from the interests of various parties, both government, society, businessmen and the international community. Therefore, in every process of criminalization, something that disturbs the community needs a holistic and comprehensive study by paying attention to the community.

This is reinforced by the Mirror concept put forward by Tamanaha, namely "the law must be a reflection of society or community where the law is applied" (law is a mirror of society, which fucntions to maintain social order) (B.Z. Tamanaha, 2001). This Tamanaha view gives a new color in jurisprudence that the law gives place and opportunity to the legal system of the nation concerned. Lawrence Friedman said that "legal systems do not float in a vacuum of culture, free from space, time and social context, but the legal system describes and reflects the things that happen to society". Vago added that "the law reflects intellectual, social, economic and political conditions during the time" (B.Z. Tamanaha, 2001). 
In particular, Werner Menski also criticized western legal experts who equated the legal system of a nation as follows, "as western academics we seem, by our own history and training, to be too informed to see and study law that does not take sufficient account of the culture-specific embeddedness of legal phenomena in the world" (Jensen, Michael C. And WH McKling, 1976). This is also to prevent the occurrence of legal gap in the law which may occur due to the differences in cultural character embraced by a nation which will affect the behavior of the law that exists in a society. Understanding differences between places also means differences between socio-cultural contexts, and no longer because of the inter-time context transition.

Public accountant is the professions which born and grow from the public demand for an independent communication mechanism between economic entities and stakeholders, primarily concerned with the accountability of the entities concerned. Professional accounting services are the exclusive rights of public accountants, and the work results of public accountants are used by the public (users of financial statement) as one of the material in making economic decision. Users of the public accountant work are not only clients who provide assignments, but also the public (investors/shareholders, creditors, government, community). In Indonesia, the law that specifically regulates the public accounting profession as a whole has not yet existed, before the Law Number 5 of 2011 concerning Public Accountants was issued. Law Number 34 of 1954 concerning the Use of Accountants, which consists of seven articles, has not yet regulated the overall profession of the public accounting, and was not in accordance with the development of the current public accounting profession. Law Number 34 of 1954 has not regulated the fundamental matters in the public accounting profession as in Law Number 5 of 2011. The responsibility of the public accountant for the financial statements examined under the opinion which has been given. The purpose of the audit is to provide an opinion on whether the financial statements reflect the financial position, results of operations, and changes in the company's financial position properly in accordance with the Financial Accounting System that is consistently applied.

Indeed, Law Number 5 of 2011 concerning Public Accountant has answered the absence of legislation on the profession of public accounting in Indonesia. However, after the Constitutional Court Decision Number 84 of 2011 which gave privileges to the profession of public accounting without criminal prosecution, the public accountant still demanded that professionals be more thorough in carrying out their audit duties. 


\section{The Essence of Criminal Accountability in Financial Statements of Public}

Accountant

There are two terms that refer to accountability in the legal position of legal subjects in the legal dictionary, i.e. liability and responsibility. Liability is a broad legal term that refers to almost any character of risk or responsibility, which is certain, which depends or may include all the actual or potential rights and obligations such as losses, threats, crimes, costs or conditions that create the duty to implement the law invited (R. Soesilo, 1976). Meanwhile, responsibility means things that can be held accountable for an obligation, and includes decisions, skills and abilities which also include the obligation to be responsible for the laws implemented (R. Soesilo, 1976). In the context of practical, the term liability refers to legal liability, i.e. accountability due to mistakes made by legal subjects, while the term responsibility refers to political responsibility (Ridwan H.R, 2006).

Roscoe Pound, a great 20th century philosopher, has a doctrine related to accountability or known as the concept of "liability" which means "use simple word liability for the situation whereby one may be legally and other is legally subjeced to the exaction". Criminal liability is defined by Pound as an obligation to pay retribution that will be received by the perpetrator from someone who has been harmed (S. R Sianturi, 1996).

Based on the Criminal Responsibility Theory which in foreign languages is referred to as "toereken-baarheid" ("criminal liability" or "criminal responsibility") (Moeljatno, 2015). The criminal liability of public accountant is intended to determine whether a public accountant in carrying out his profession can be subject to criminal liability based on the actions.

Meanwhile, the basis of criminal acts is the principle of legality, while the basis of being able to be prosecuted by someone is a mistake, which means that a person cannot be accounted for and sentenced to a criminal offense if they are not conducted any unlawful act (Romli Atmasasmita, 2017). A person who commits a criminal act can be convicted if he/she has a mistake and when someone can be said to have a msitake. In order to determine the existence of a person's msitake, it should meet several elements, such as: (a) the ability to be responsible; (b) the inner relationship between the accused and his actions in the form of intentions (dolus) or negligence (culpa) hereinafter referred a form of error; and (c) there is no reason for eliminating mistake or there is no reason to forgive (Romli Atmasasmita, 2017).

In regard to the relation with the public accounting profession, the chance of an element of error is in the misleading financial statement (fraud). Criminal acts have consequences for accountability and criminal charges. According to Tunggal, an action is said to be fraud, if: (a) there must be an incorrect 
presentation (misrepresentation) if it fulfills several elements, where all elements must be present, if there are none, then fraud is not considered; (b) from a past or present; (c) the fact is material (material fact); (d) carried out intentionally or without calculation (make-knowingly or recklessly); (e) with intent to cause the other party to react; (f) the damaged party must react (acted) to misrepresentation; (g) resulting in detriment (Amin Widjaja Tunggal, 2001).

Furthermore, according to Razae and Riley, there are three elements that must be considered by the company management if they want to prevent fraud, such as: (a) creating and restoring a culture that respects honesty and high ethical values; (b) the application and evaluation of the anti-fraud control process; (c) development of oversight process (oversight process).

Association of Certified Fraud Examination (ACFE), which is one of the associations in the United States that devotes its activities to fraud prevention and eradication, categorized fraud into three sectors and fraud detection actions based on those sectors, i.e. (a) fraudulent financial statements; (b) misuse of assets (assets misappropriation); and (c) corruption (Theodorus M. Tuanakotta, 2010). The factors that cause a person to commit fraud are three things: pressure, opportunity, and rationalization.

The purpose of the financial statement audit by independent auditors in general is to express opinions about fairness, in all material respects, financial position, results of operations, changes in equity, and cash flows in accordance with generally accepted financial accounting standards in Indonesia. The auditor is responsible for planning and carrying out an audit in order to obtain sufficient confidence regarding whether the financial statements are free of material misstatement, whether caused by errors or fraud. Financial statements are the responsibility of management. However, the public accounting profession is often criminalized because of financial statements.

The application of approved procedures to prospective financial statements of the accountant can carry out the approved procedure attestation agreement on prospective financial statements under the following conditions: (a) the accountant is independent; (b) certain accountants and users agree on procedures implemented or must be carried out by accountants; (c) certain users assume responsibility for the adequacy of approved procedures to fulfill their objectives; (d) prospective financial statement include a summary of significant assumptions; (e) prospective financial statements that are treated with approved procedures can be estimated or measured in a reasonable and consistent manner; (f) criteria that must be used in determining the findings agreed between accountants and certain users; (g) the procedure applied to a perspective financial statement is expected to produce findings that are reasonably consistent using these criteria; 
(h) evidence relating to prospective financial statement that are treated with agreed procedures is expected to provide an adequate basis for stating findings in the accountant's report; (i) if applicable, an explanation of agreed materiality limits for reporting purposes; ( $\mathrm{j}$ ) the use of the report must be limited to certain users (Alvin A. Arens, Randal J. Elder, Mark S. Beasley, 2003).

According to Statement of Financial Accounting Standards Number 1 of the Financial Accounting Standards, the function of financial statement in a company is as a tool of accountability in the dissemination of information by the management (directors) to the owner or to the public. Complete financial statements consist of five components, such as: balance sheet, income statement, statement of changes in equity, cash flow statements, and notes to financial statement. Financial statements are information that is very much needed in decision making. Financial statements or commonly referred to as annual reports in the Limited Liability Company Law are regulated in Chapter IV, Part Two which consists of the provision of Articles 66 to Article 69.

\section{Civil Accountability of Public Accountant in the Indonesian Legal System}

In the worst case, failure in fulfilling obligations, either as a result of defaults (Article 1243 of Civil Code) or unlawful acts (Article 1365 of Civil Code) which are legally (by law) based on Article 1131 of the Civil Code, will provide consequences for punishing those who have carried out default or unlawful acts to pay for all losses from the aggrieved parties by using all of their property, not only those that already exist but also those that will exist.

In the event of a violation committed by a public accountant in providing services, both the findings of any violations that are of minor violations and those form of serious violation, based on PMK Number 17 / PMK.01 / 2008 are only subject to administrative sanctions, in the form of sanctions warning, permit freezing and sanctions for revocation of licenses as regulated, among others, in Article 62, Article 63, Article 64 and Article 65.

Some of the legal obligations of public accountants are:

a. Liabilities to client. Liability of public accountants to clients due to failure to carry out audit function in accordance with approved time, conducting inadequate audits, failing to meet errors, and violating confidentiality by public accountants;

b. Liability to third parties according to Common Law (liabilities to third party) Liability of public accountants to third parties if there is a loss to the plaintiff due to the rely on misleading financial statements;

c. Civil liability under federal securities law (liabilities under securities laws).

Legal obligations governed by federal securities with strict standards; 
d. Criminal liability (crime liabilities). Legal obligations that arise as a result of the possibility of public accountants being blamed for criminal acts according to the law.

Whereas the legal obligations governing public accountants in Indonesia explicitly has not been existed yet, but implicitly this already exists as stated in the Public Accountant Professional Standards, Financial Accounting Standards, Regulations concerning to Capital Markets or Service Authorities Finance, Taxation Law and others relating to the legal obligations of Public Accountant.

Unlawful acts in Indonesia normatively always refer to the provisions of Article 1365 of the Civil Code. The formulation of this norm in this article is unique, unlike the provisions of other articles. Formulation of norms in Article 1365 of the Civil Code is a norm structure than the substance of legal provisions that has been completed. This results in the substance of the provisions in Article 1365 of the Civil Code which always requires materialization outside the Civil Code. Unlawful acts are born because of the principle that whosoever commits an act that brings harm to another person requires a person who, because of the fault, compensates for the loss. While an unlawful act and liability can be requested to pay compensation if it fulfills the following elements: (a) element of action; (b) elements against the law; (c) element of error; (d) element of loss; (e) there is a causal relationship between actions and losses.

The existence of legal instruments that regulates public accountants in Indonesia is demanded by the public, including the professional community to complete the existing rules of the game. This is necessary in one hand that the profession can carry out its professional responsibilities with a high level of compliance, and on the other hand the community will have a strong foundation if at any time they will prosecute professional responsibilities. In this case, public accountants are only responsible for opinions regarding financial statements and those opinions must have integrity and professional competency based on established standards. Therefore, legal liability is not a threat to the auditor but rather a challenge to work more professionally and independently.

Audited financial statement can consequence in errors, and the Public Accountants Act provides legal protection against them. It could happen if there are misleading financial statements or misleading information due to misrepresentation or omission. Misrepresentation can occur if a report is clearly not in accordance with the facts. Therefore, misrepresentation is sometimes referred to as misstatement, which is an act that makes a false statement, especially with regard to internal data that can be misleading to investors. Thus the violation of the disclosure principle in the form of "misleading statements" must be legally accounted. 
Article 93 of the Capital Market Act concerning to the prohibition of misleading statements states that every party is prohibited, in any way, from making a statement or giving a statement that is materially incorrect or misleading so that it affects the price of securities on the stock exchange when the statement is made or statement is given:

a. The party concerned knows or deserves to know that the statement or statement is materially incorrect or misleading; or

b. The party concerned is not careful enough in determining the material truth of the statement or statement.

Misleading statements can lead to fraudulent actions. In the view of capital market law, violations of the rules on the disclosure principle are categorized as fraud. This is also supported by Barry. A.K. Rider who stated that "sun light is the best disinfectant and electric light the best policeman". In other words, Rider stated "more disclosure will inevitably discourage wrongdoing and abuse". In this regard, directors are jointly responsible for submitting misleading financial statements. In the Capital Market Supervisory Agency Regulation, Regulation Number VIII.G.11 concerning the Responsibility of the Board of Directors for Financial Statements in Number 4, it is stated that the directors of issuers or public companies are jointly and severally responsible for statements made under this regulation including losses that may caused.

The application of joint responsibility is the legal will of the Indonesian Limited Liability Company, which was only known in Law Number 40 of 2007 concerning Limited Liability Companies (UUPT). In the previous regulation both in the Code of Commercial Law (KUHD) and Limited Liability Company Law of 1995, as well as the Bapepam Regulation Kep-40/PM/2003 stated that the responsibility of directors for financial statements is the principle of personal responsibility which depends on the factors who do mistake, negligence or violation. Its legal responsibility is only borne by the directors who do it. Does not involve other members of the board of directors jointly and severally.

Furthermore, article 97 paragraph (4) of the Limited Liability Company Law adheres to the principle of enforcing joint responsibility on each member of the board of directors for errors and negligence in management carried out by other members of the board of directors. However, the application of this principle can be removed by members of the board of directors who do not participate in making mistakes or negligence if the member of the board of directors "can prove" the following matters:

a. The company's loss was not due to an error or negligence;

b. Has carried out and carried out the management of the Company in good faith and prudence for the interests of the Company in accordance with the 
purposes and objectives of the Company stipulated in the company's articles of association;

c. Do not have a conflict of interest, either directly or indirectly, for the management action that results in the Company's loss;

d. Has taken action to prevent such losses from arising or continuing. According to the explanation of Article 97 paragraph (5) letter d, what is meant by "taking actions to prevent arising or continuing losses", including steps to obtain information about management actions that can result in losses, among others, through the board of directors meeting forum.

The requirement to be released referred above are cumulative and not alternative. That was concluded from the formulation. Between the terms of letters a, b, c, and d, there is no word "or". There is the word "and" between letters $a, b, c$, and $d$. Starting from the facts of the formulation mentioned above, it can be concluded, these conditions are cumulative.

In order for a member of the board of directors to be protected and free from joint responsibility for the errors and omissions of other members of the board of directors in the management of the Company, the member of the board of directors must prove the matters referred to in article 97 paragraph (5) letter $a, b$, $\mathrm{c}$, and $\mathrm{d}$ above. One thing cannot be proven, the enforcement of the principle of responsibility must be applied jointly as determined in article 97 paragraph (4) of the Company Law. The regulation on the implementation of the disclosure principle in the Indonesian capital market regime has contained provisions regarding the prohibition of misleading acts, both in the prospectus and in the mass media relating to a public offering. In addition, the provisions on the prohibition of misleading acts have stipulated sanctions in the form of a maximum imprisonment of 10 (ten) years and a maximum fine of $\mathrm{Rp}$. $15,000,000,000.00$ (fifteen billion rupiah) for violations of these acts. However, the regulation on the implementation of the principle of transparency which contains provisions prohibiting misleading acts is very simple and inadequate to regulate the elements of misleading actions. For example, article 78 of Law Number 8 of 1995 concerning the Capital Market determines that it is not permissible to make material fact statements that are false or do not contain true material facts. Other restrictions can also be seen in article 93 of Act Number 8 of 1995 concerning Markets Capital, which prohibits a person in any way from making a statement or providing information that is materially incorrect or misleading, which can affect the price of shares on the Stock Exchange. 


\section{E. CLOSING}

\section{Conclusion}

The position of the Public Accountant shows responsibility for the profession, and is fully responsible in accordance with the laws and regulations, especially in Law Number 5 of year 2011, concerning Public Accountants. So that the quality of work runs in accordance with the Professional Standards of Public Accountants. The Criminal Accountability of Public Accountants for audited financial statements is in the form of intentions so that actions due to misconduct carried out by the Auditee (the company be examined) are omissions, could not be charged by the Public Accountant.

\section{Recommendation}

Public Accountants should work in accordance with the Professional Standards of Public Accountants, by submitting audited financial statements based on material facts or the presentation of financial statements that have been presented in accordance with Financial Accounting Standards. Thus that if the Auditee has decreased productivity or performance in the company, the board of commissioners and directors can take an attitude and action for the survival of the company audited by a Public Accountant, that the Public Accountant is not easily criminalized. The Indonesian Accountant Code of Ethics Council must maintain and strive to decriminalize the profession of the Public Accountant. In addition, with the existence of a code of ethics, the public will be able to assess the extent to which a Public Accountant has worked in accordance with professional standards and ethical standards set by the profession. The performance of the Public Accountant is an action or implementation of audit tasks that have been completed by a Public Accountant in a certain period of time, and with the Decision of the Constitutional Court can prevent the criminalization of Public Accountant. 


\section{BIBLIOGRAPHY:}

\section{Books:}

Alvin A. Arens, Randal J. Elder, Mark S. Beasley, 2003, Auditing dan Pelayanan Verifikasi Pendekatan Terpadu (Auditing and Integrated Approach Verification Services), Edisi Kesembilan, Jilid 1, Indeks Kelompok Gramedia: Jakarta.

Moch Koesnoe, 1981, Kritik Terhadap Ilmu Hukum, Lembaga Riset dan Pengabdian Masyarakat (Criticism of Law, Research, and Community Service Institutions). Fakultas Hukum Universitas Islam Indonesia: Yogyakarta.

Moeljatno, 2015, Asas-Asas Hukum Pidana (Criminal Law Principles), Edisi Kesembilan. Rineka Cipta: Jakarta.

Mulyadi, 1990, Pemeriksaan Akuntan (Accountant Examination), Edisi 3. Bagian Penerbitan Sekolah Tinggi Ilmu Ekonomi YKPN: Yogyakarta.

R. Soesilo, 1976, Kitab Undang-Undang Hukum Pidana (Criminal Code), Penerbit Politeia: Bogor.

H.R. Ridwan, 2006, Hukum Administrasi Negara (Administrative Law) ,Raja Grafindo Persada: Jakarta.

Romli Atmasasmita, 2017, Reskontruksi Asas Tiada Pidana Tanpa Kesalahan (Reconstruction of The Principle of 'No Criminal Without Mistakes', PT. Gramedia Pustaka Utama: Jakarta.

S.R. Sianturi, 1996, Asas -Asas Hukum Pidana Indonesia dan Penerapannya (Indonesian Criminal Law Principles and Its Application), Cetakan IV. Alumni Ahaem-Pateheam: Jakarta.

Gatot Supramono, 2007, Hukum Perseroan Terbatas (Private Company Law). Penerbit Djambatan: Jakarta.

B. Z. Tamanaha, 2001, A General Jurisprudence of Law and Society. Oxford University Press: London.

Tuanakotta M. Theodorus, 2010, Akuntansi Forensik dan Audit Investigatif (Forensic Accounting and Investigative Audit), Penerbit Salemba Empat: Jakarta.

Amin Widjadja Tunggal, 2001, Pemeriksaan Kecurangan (Fraud Auditing). Jakarta: Haravavindo.

\section{Journals/ Paper/ Reports:}

Michael C. Jensen, and W.H. McKling, 1976, "Theory of The Firm: Managerial Behavior, Agency Cost and Ownership Structure" Journal of Financial Economics, Vol. 3 Issue 4.

492 Yustisia Vol. 7 Number 3 (Sept.-Dec. 2018) $\quad$ Legal Accountability Of Public ... 
Mardiasmo, 2006, "Pewujudan Transparansi dan Akuntabilitas Publik Melalui Akuntansi Sektor Publik”. Jurnal Akuntansi Pemerintah, Vol. 2, No. 1.

Nasution Bismar, 2001, "Kepentingan Pasar Modal dalam Rancangan Perubahan Undang-Undang Kepailitan”. Makalah disampaikan pada Lokakarya Mengenai Rancangan Perubahan Undang-Undang Kepailitan, kerjasama antara Dirjen Pembinaan BUMN, Jakarta Stock Exchange, Pasca Sarjana USU, Fakultas Hukum UI dan University of South Carolina, Medan 7 Desember, 2001.

Soetandyo Wignyosubroto, 1995, "Sebuah Pengantar Ke Arah Perbincangan tentang Pembinaan Penelitian Hukum Dalam PJPT II." Makalah Disampaikan Dalam Seminar Akbar 50 Tahun Kemerdekaan, BPHN, Departemen Kehakiman, Jakarta. 